\title{
A Review Study of the Human Resource Management Practices on Job Satisfaction of Hotel Industry Employees of Malaysia
}

\author{
Md Murad Miah \\ MSc in Business Management \\ Faculty of Business Management \\ Universiti Teknologi MARA (UiTM) \\ 40450 Shah Alam, Selangor \\ E-mail: muradmiah1996@gmail.com \\ Dr Nor Intan Adha Hafit \\ Faculty of Business Management \\ Universiti Teknologi MARA (UiTM) \\ 40450 Shah Alam, Selangor
}

Received: May 21, 2019 Accepted: June 12, 2019 Online published: July 8, 2019

doi:10.5296/ijhrs.v9i3.15046ＵRL: https://doi.org/10.5296/ijhrs.v9i3.15046

\begin{abstract}
The purpose of this review study to determine the impact of human resource management practices on job satisfaction. In addition, in this research is deeply focusing on job satisfaction, various human resource management practices, hotel industry of Malaysia, providing some prior relevant theoretical model, the relationship between HRM practices and job satisfaction and hypotheses has been developed. Based on this review of existing literature has been identified that there is a lot of HR management lacking in the hotel industry of Malaysia namely; shortage of talented people, high turnover issue, lack of adequate training, lack of motivation and lack of quality services. However, based on the existing literature it is proven that there is a significant relationship between HRM practices and job satisfaction. Therefore, this study will contribute in two ways namely; In practicallyhelps the management of hotel industry to understand the relationship between HRM
\end{abstract}


practices and job satisfaction, keep motivating and retaining skillful employees, attract talent people and reduce the turnover issue and finally developed the competitive advantage among its rivals. In theoretically- this research will be the reference for the future research on HRM practices and job satisfaction. Other than that, the conceptual framework is plain and simple that is easy to understand for the relationship between HRM practices and job satisfaction which will help other researchers to think wisely about the relationship.

Keyword: job satisfaction, HRM practices, hotel industry of Malaysia, conceptual framework on job satisfaction

\section{Introduction}

At present, globally hotel industry facing high competition with each other due to globalization, technological innovation, almost similar service offering and lack of talented people for quality service (Salguero, 2019; Tran, 2015; Mathews, 2000). In addition, to sustain in the competitive business environment, the hotel industry to be creative performer, quality service provider and need to retain talented employees in the hotel industry. Most of the researchers suggested that employee retention is one of the essential elements for survive and sustain in the market because every intangible source can duplicate by other organization except talent and knowledge of employee (nontangible) (Yao et all, 2019; Pandey et all, 2019; AlBattat, 2013).

The hotel industry is one of the important service-based organization in the current business environment, as particular for Malaysia (Abo-Murad \& Abdullah, 2019). In this sector, Marketing strategy, quality service, and innovation make the organization successful as its operation (Karakaş et all, 2019: Ottenbacher, 2007; Gray et all, 2000). Other than that, hotel industry services little bit deference from each other this is why it is facing high competition nowadays. However, in Malaysia, the hospitality sector is the 3rd GDP contributor where the hotel industry made a significant aspect in the hospitality industry (Ministry of Tourism Industry, 2018).

\begin{tabular}{l|l|l}
\hline Year & Arrivals (tourist) & Receipts (RM) \\
\hline 2018 & 25.83 Million & 84.1 Billion \\
\hline 2017 & 25.95 Million & 82.1 Billion \\
\hline 2016 & 26.76 Million & 82.1 Billion \\
\hline 2015 & 25.72 Million & 69.1 Billion \\
\hline 2014 & 27.44 Million & 72.0 Billion \\
\hline 2013 & 25.72 Million & 65.4 Billion \\
\hline 2012 & 25.03 Million & 60.6 Billion \\
\hline 2011 & 25.71 Million & 58.3 Billion \\
\hline 2010 & 24.58 Million & 56.5 Billion \\
\hline 2009 & 23.65 Million & 53.4 Billion \\
\hline 2008 & 22.05 Million & 49.6 Billion \\
\hline 2007 & 20.97 Million & 53.4 Billion \\
\hline
\end{tabular}

Source: Ministry of Tourism Malaysia (2018) 
Accessible online www.tourism.gov.my/statistics

From the table above, it is proven that how the hotel industry day by day increasing their profit and Malaysia become one of the most attracting places around the world. In addition, the Ministry of Tourism Malaysia places a significant contribution to developing, marketing and coordinate all the procedure to attract foreign tourist coming in Malaysia. As a result, Malaysia becomes the third most popular tourist destination in Asia reported by (World Travel Monitor, 2018; Din, 2018). Unfortunately, from the of the beginning of Malaysia's hotel industry until the recent time there are lots of HR problems are facing by hotel industry namely; shortage of talented people, high turnover rate, lack of employee motivation, lack of employee adequate training, lack of quality service( Haldorai et all 2019, Beh et all, 2017; Zainol, 2015; Downe et all, 2012). Therefore, in the hotel industry of Malaysia cannot retain their staff for a long time. Likewise, in Malaysia, the Malaysian Employers Federation (2011) reported that the turnover rate in the hotel industry is $65.7 \%$ (Zainol et al., 2015).

Therefore, this study will help both ways in practically and theoretically as well. In practically, this study will give certain guideline by establishing the relationship between HRM practices and job satisfaction. Secondly, this study also helps the hotel manager to attract talent employee, keep motivating, and retaining skillful employees in the hotel that will provide a competitive advantage among its rivals. Besides that, this study will provide some deep knowledge of understanding about particular HRM practice that mostly relates to job satisfaction.

In theoretically, this study will propose a framework that will contribute to the knowledge of HRM practices and job satisfaction. Other than that, this research will provide guideline for future researcher to identify or examine the relationship between HRM practices and job satisfaction.

\section{Literature Review}

\section{HRM practices and Job satisfaction}

\section{Training and development}

Nowadays, Training and development is a crucial term for every business to make employees extraordinary and updated skills of workers. The business world becoming more challenging and competitive. To endure and sustain in the dynamic business environment all the time coming new challenges in front of the organization (Pati \& Das, 2018). Therefore, the organization needs to work constantly on different strategies to remain in the market and give the best service of the potential target customers. Moreover, it is just conceivable if the employees get well trained and upgrade their skills and apply in their area of the job. To accomplish a competitive advantage and best outcome organization must need to upgrade employee skills where they can do their best on their job (Aguenza \& Som, 2018). As a result, employees will be motivated, can reduce the absenteeism and employees will be effective and efficient on their job.

Thus, Trained employees were more satisfied than untrained employees (Kiruja \& Mukuru, 
2018). Typically, when employees are participating in the training and development programs, they get an opportunity to improve their present aptitudes and furthermore can resolve new skills that may be required in the future. Amid the session of training and development, employees comprehend their core competency and which side they are performing admirably. Other than that, employees also comprehend the lacking behind of underperformance. So is the way, the employees have recognized that the organization is helping them to build their abilities and if they will they feel that on the off chance that they will have a type of issue in regards to performance they, by taking an interest in training and development programs can resolve those issues and in result they are satisfied that they are being esteemed by organization and organization is putting resources into them. These all variables prompting fulfillment to result in highly improved employee performance. when the employees are satisfied, and they realize that their organization is spending a lot of money in training and development programs they consequently want to return back to the organization by demonstrating to them their improved performance. As the employees are happy with their job, they don't feel any stress or burden, which are most regular explanations behind employee's terrible execution, the employees are cheerful, and it is a typical observation that happy employees are good performers.

\section{H1. There is a significant relationship between training and development and job satisfaction}

\section{Performance Appraisal}

Performance appraisal is considered to encourage employees in the subsequent performance cycle (Rubin \& Edwards, 2018). Rubin also mentioned that there is expanded utilization of execution appraisal process which is, for the most part, persuaded by a hierarchical need an impact on employee' attitude, behaviors, just as organizational execution as well. The result will be built upon establishments that set toward the start of the appraisal cycle which is help employees to draw out their undeniable execution objectives see, the administering of execution amid the evaluation which helps the poor performers and furthermore backings to give the top-notch execution in the organization (Gladisa \& Susanty, 2018). The ability to accomplish these positive results will be in the capacity of the execution evaluation experience (Darehzereshki, 2013).

H2: There is a significant relationship between performance appraisal and job satisfaction

\section{Compensation and Benefits Package}

Previous studies have shown that compensation influences work fulfillment employees anticipate a specific dimension of money related prizes for their authoritative commitment and pay establishes a quantitative proportion of a worker's value. To compete the most talented employee, organizations need to give appealing and fair pay. It has been contended that compensation is a help for some workers at first, however, it's anything but an amazing inspiration over the long haul. The job of pay in drawing in and holding individuals at work has been perceived for a long time and is progressively essential in the present economic 
condition where key pay planning is required (Jackson and Schuler, 2006).

Other than that, particularly in the developed world, worker benefits package has turned into a vital piece of the absolute remuneration or authoritative costs. Employees advantages normal $40 \%$ of the complete pay package (DeCenzo and Robbins, 2010). Benefits have developed in size, significance and assortment (DeCenzo and Robbins, 2010; Edgar and Geare, 2005), and the U.S. Chamber of commerce, reasons that employees' benefits are one of the best difficulties in business today in pulling in and holding quality workers (Eisenberg, 2009 ; U.S. Chamber of Commerce, 2008). This development proposes that employees progressively esteem worker benefits as a major aspect of their general remuneration package

\section{H3: There is a significant relationship between compensation and benefit pakages and job satisfaction}

\section{Promotion Practices}

Promotion can be characterized as the movement of an individual to a more elevated level position in an organization (Ozel \& Bayraktar, 2018). This is an open door given by the organization towards its employees, and typically just the individuals who accomplished the standard set by the organization might be promoted. Promotion is likewise a vital part of employee's career and life, influencing other aspects of the work experience including employees' work versatility that brought about the compensation builds (Kosteas, 2009). Promotion opportunity is constantly connected with an expansion in workload and responsibility. Kosteas (2011) expressed that promotion could significantly affect other occupation attributes, for example, duties and enduring job attachment. Firms can utilize promotion as a reward for exceedingly gainful workers, creating a motivator for workers to apply more noteworthy exertion. promotions might be a successful component for inspiring more prominent exertion if workers place a noteworthy incentive on the promotion itself.

\section{H4: There is a significant relationship between promotion practices and job satisfaction}

\section{Work Environment}

Raziq \& Maulabakhsh (2015) found that for the workers who work under troublesome working conditions, working condition is an imperative factor for employment fulfillment, so specialists under troublesome working conditions are disappointed through this factor. To improve the fulfillment of employees working under troublesome working conditions, it is fundamental for the organization to improve the working conditions. This will make them similarly happy with the individuals who work under typical working condition and consequently in general execution will increment. Hanaysha (2016) uncovered that there are diverse factors like workload, compensation, stress at work spot and conflict with family due to occupation drives a worker towards disappointment that further Job results in a turnover. At conclusive stage these free factors impact adversely on authoritative execution which is contrarily affected by these components. Hanaysha (2016). contend that an organization needs to focus on making a workplace that improves the capacity of employees to end up progressively gainful so as to build benefits for the organization. He likewise contended that 


\section{Macrothink}

International Journal of Human Resource Studies

ISSN 2162-3058 2019, Vol. 9, No. 3

Human to human collaborations and relations are assuming the progressively predominant job in the general employment fulfillment as opposed to money while the management aptitudes, time and vitality, all are required for improving the general execution of the organization in current time.

\section{H5: There is a significant relationship between work environment and job satisfaction}

\section{Conceptual framework}

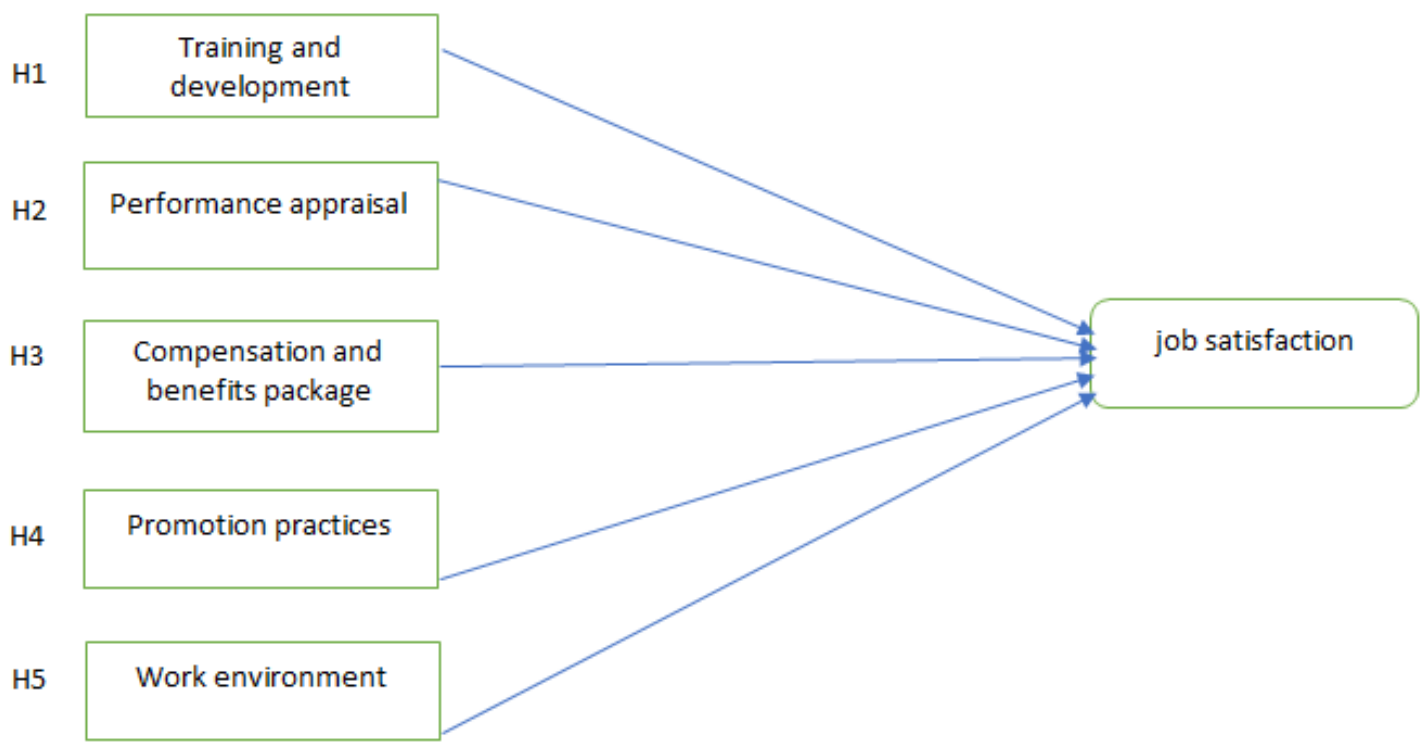

\section{Conclusion}

This is the review paper on human resource management practices and job satisfaction which is focused on the hotel industry employees of Malaysia. However, there is a number of studies have been done on the field of human resource management practices and job satisfaction, where the maximum study has been proving that there is a significant relationship between human resource management practices and job satisfaction. Other than that, it is also found that due to the lack of HR practices in the organization, employees are becoming demotivated, absenteeism, far from organization mission, less innovative, and finally turnover from the organization. Therefore, due to the turnover issue, there is a shortage of talented people, less attractive to young talent in the hotel industry in Malaysia and around the world. Furthermore, previous researchers also found that HR practices can impact on employees' attitude, willingness, satisfaction, commitment, motivation and finally employees are becoming loyal to the organization.

Consequently, this research will give in-depth understanding as a hotel manager to use the proper HR practices to their employees which will motivate and retain employees in an organization for a long time. Other than that, this research is providing a guideline for future research on the field of HRM practices and job satisfaction. However, there is the number of limitations have this study namely: it is a review paper base on the previous research therefore future research can continue to identify as the current job satisfaction level of hotel 
industry employees by primary data. Other than that, this paper focus on the hotel industry, hence, future research can be done on other sectors to find out the different concept that will cover a significant gap of this study.

\section{Acknowledgement}

This is the collaborative research, where my main supervisor Dr Nor Intan Adha Hafit motivate and cooperate me to do a research on his field. In addition, this research activity also helps me to fulfill the requirement of MSc in Business Management.

\section{References}

Abo-Murad, M., \& Abdullah, A. K. (2019). TURNOVER CULTURE AND CRISIS MANAGEMENT: INSIGHTS FROM MALAYSIAN HOTEL INDUSTRY. Academy of Strategic Management Journal, 18(2).

Abu Bakar, R., Cooke, F. L., \& Muenjohn, N. (2018). Religiosity as a source of influence on work engagement: a study of the Malaysian Finance industry. The International Journal of Human Resource Management, 29(18), 2632-2658. https://doi.org/10.1080/09585192.2016.1254103

Aguenza, B. B., \& Som, A. P. M. (2018). Motivational factors of employee retention and engagement in organizations. IJAME, I(6), 88-95.

AlBattat, A. R. S., \& Som, A. P. M. (2013). Employee dissatisfaction and turnover crises in the Malaysian hospitality industry. International Journal of Business and Management, 8(5), 62. http://dx.doi.org/10.5539/ijbm.v8n5p62

Bailey, C., Mankin, D., Kelliher, C., \& Garavan, T. (2018). Strategic human resource management. Oxford University Press.

Banfield, P., Kay, R., \& Royles, D. (2018). Introduction to human resource management. Oxford University Press.

Beh, L. S., \& Shah, S. H. A. (2017). Skills Enhancing Practices on Turnover Intentions: Mediating Role of Affective Commitment in Hotel Industry, Malaysia. Advanced Science Letters, 23(9), 9208-9214. https://doi.org/10.1166/asl.2017.10056

Berman, E. M., Bowman, J. S., West, J. P., \& Van Wart, M. R. (2019). Human resource management in public service: Paradoxes, processes, and problems. CQ Press.

Brewster, C., \& Cerdin, J. L. (2018). HRM in Mission Driven Organizations. https://doi.org/10.1007/978-3-319-57583-4

Chin, C. L. (2018). The Influence of Job Satisfaction on Employee Turnover Intention in the Manufacturing Industry of Malaysia. Journal of Arts \& Social Sciences, 1(2), 53-63.

Darehzereshki, M. (2013). Effects of performance appraisal quality on job satisfaction in multinational companies in Malaysia. International Journal of Enterprise Computing and Business Systems, 2(1), 1-18. 
DeCenzo, D. A., \& Robbins, S. P. (2010). Human Resource Management, International Student Version. John Wiley \& Sons.

Din, K. H. (2018). Dialogue with the hosts: An educational strategy towards sustainable tourism. In Tourism in South-East Asia (pp. 345-354). Routledge.

Downe, A. G., Loke, S. P., Ho, J. S. Y., \& Taiwo, A. A. (2012). Corporate talent needs and availability in Malaysian service industry. International Journal of Business and Management, 7(2), 224. http://dx.doi.org/10.5539/ijbm.v7n2p224

Edgar, F., \& Geare, A. (2005). HRM practice and employee attitudes: different measures-different results. Personnel review, 34(5), 534-549.

Eisenberg, T. (2009). US Chamber of Commerce liability survey: Inaccurate, unfair, and bad for business. Journal of Empirical Legal Studies, 6(4), 969-1002.

Gladisa, F. W., \& Susanty, A. I. (2018). Determinant factors of employee satisfaction in the performance appraisal based on management by objectives. Sustainable Collaboration in Business, Technology, Information and Innovation (SCBTII), 1(1).

Glaister, A. J., Karacay, G., Demirbag, M., \& Tatoglu, E. (2018). HRM and performance - The role of talent management as a transmission mechanism in an emerging market context. Human Resource Management Journal, 28(1), 148-166. https://doi.org/10.1111/1748-8583.12170

Gray, B. J., Matear, S. M., \& Matheson, P. K. (2000). Improving the performance of hospitality firms. International Journal of Contemporary Hospitality Management, 12(3), 149-155. https://doi.org/10.1108/09596110010320643

Haldorai, K., Kim, W. G., Pillai, S. G., Park, T. E., \& Balasubramanian, K. (2019). Factors affecting hotel employees' attrition and turnover: Application of pull-push-mooring framework. International Journal of Hospitality Management, 83, 46-55. https://doi.org/10.1016/j.ijhm.2019.04.003

Hanaysha, J. (2016). Work Environment and Organizational Learning as Key Drivers of Employee Productivity: Evidence from Higher Education Sector. International Journal of Human Resource Stud-ies, 6(2), 1-13. http://dx.doi.org/10.5296/ijhrs.v6i2.9203

Hussinki, H., Kianto, A., Vanhala, M., \& Ritala, P. (2019). Happy Employees Make Happy Customers: The Role of Intellectual Capital in Supporting Sustainable Value Creation in Organizations. In Intellectual Capital Management as a Driver of Sustainability (pp. 101-117). Springer, Cham. https://doi.org/10.1007/978-3-319-79051-0_6

Jackson, S. E., \& Schuler, R. S. (2006). Human resource management: international perspectives. Thomson South-Western.

Kampkötter, P., Harbring, C., \& Sliwka, D. (2018). Job rotation and employee performance-evidence from a longitudinal study in the financial services industry. The International Journal of Human Resource Management, 29(10), 1709-1735. 
https://doi.org/10.1080/09585192.2016.1209227

Karakaş, A., Bilgin, Y., \& Yildiz, M. R. (2019). Impact of Managers' Innovation Perception on Innovation Activities and Innovation Strategies in Hotel Businesses. In Eurasian Economic Perspectives (pp. 55-70). Springer, Cham. https://doi.org/10.1007/978-3-030-11833-4_4

Kiruja, E. K., \& Mukuru, E. (2018). Effect of motivation on employee performance in public middle level technical training institutions in Kenya. IJAME, 11, 1597.

Kooij, D. T., \& Boon, C. (2018). Perceptions of HR practices, person-organisation fit, and affective commitment: The moderating role of career stage. Human Resource Management Journal, 28(1), 61-75. https://doi.org/10.1111/1748-8583.12164

Kosteas, V. D. (2009). Job level changes and wage growth. International Journal of Manpower, 30(3), 269-284. https://doi.org/10.1108/01437720910956763

Kosteas, V. D. (2011). Job satisfaction and promotions. Industrial Relations: A Journal of Economy and Society, 50(1), 174-194. https://doi.org/10.1111/j.1468-232X.2010.00630.x

Lambert, E. G., Qureshi, H., Frank, J., Klahm, C., \& Smith, B. (2018). Job stress, job involvement, job satisfaction, and organizational commitment and their associations with job burnout among Indian police officers: a research note. Journal of Police and Criminal Psychology, 33(2), 85-99. https://doi.org/10.1007/s11896-017-9236-y

Mathews, V. E. (2000). Competition in the international hotel industry. International Journal of Contemporary Hospitality Management, 12(2), 114-118. https://doi.org/10.1108/09596110010309916

Mobley, W. H. (1977). Intermediate linkages in the relationship between job satisfaction and employee turnover. Journal of applied psychology, 62(2), 237. http://dx.doi.org/10.1037/0021-9010.62.2.237

Ottenbacher, M. C. (2007). Innovation management in the hospitality industry: different strategies for achieving success. Journal of hospitality \& tourism research, 31(4), 431-454. https://doi.org/10.1177/1096348007302352

Ozel, A., \& Bayraktar, C. A. (2018). Effect of Organizational Justice on Job Satisfaction. In Industrial Engineering in the Industry 4.0 Era (pp. 205-218). Springer, Cham. https://doi.org/10.1007/978-3-319-71225-3_18

Pandey, P., Singh, S., \& Pathak, P. (2019). Factors affecting turnover intentions in the Indian retail industry. Int. J. Human Resources Development and Management, 19(2). 10.5958/0976-173X.2018.00002.7

Pati, P., \& Das, A. (2018). Capability Development in Dynamic Business Environment: A Framework for Practitioners. IIMS Journal of Management Science, 9(1), 14-19.

Raziq, A., \& Maulabakhsh, R. (2015). Impact of working environment on job satisfaction. $\begin{array}{llll}\text { Procedia Economics } & \text { 717-725. }\end{array}$ 
https://doi.org/10.1016/S2212-5671(15)00524-9

Rubin, E. V., \& Edwards, A. (2018). The performance of performance appraisal systems: understanding the linkage between appraisal structure and appraisal discrimination complaints. The International Journal of Human Resource Management, 1-20. https://doi.org/10.1080/09585192.2018.1424015

Salguero, G. C., Gámez, M. Á. F., Fernández, I. A., \& Palomo, D. R. (2019). Competitive Intelligence and Sustainable Competitive Advantage in the Hotel Industry. Sustainability, 11(6), 1-12. https://doi.org/10.3390/su11061597

Sari, E. T. (2018). MOTIVATION AND SATISFACTION TOWARDS EMPLOYEES'LOYALTY TO ACHIEVE COMPANY'S ADVANTAGE. JMBI UNSRAT (Jurnal Ilmiah Manajemen Bisnis dan Inovasi Universitas Sam Ratulangi)., 4(1).

Shrivastava, P. (2018). Impact of effectiveness of performance management system on employee satisfaction and commitment. International Journal of Management Research and Reviews, 8(4), 1-8.

The Edge (Deember, 2009): More companies expected to lift pay freeze next year. https://www.theedgemarkets.com

Tran, X. V. (2015). Effects of economic factors on demand for luxury hotels rooms in the US. Advances in Hospitality and Tourism Research (AHTR), 3(1), 1-17.

Yao, T., Qiu, Q., \& Wei, Y. (2019). Retaining hotel employees as internal customers: Effect of organizational commitment on attitudinal and behavioral loyalty of employees. International Journal of Hospitality Management, 76, 1-8. https://doi.org/10.1016/j.ijhm.2018.03.018

Zainol, N., Ahmad, R. A., Nordin, N., Tazijan, F., Ab Rashid, P. (2015). Employees Dissastification and Turnover Crises: A Study of Hotel Industry, Malaysia (March 11, 2015). http://dx.doi.org/10.2139/ssrn.2576603

\section{Copyright Disclaimer}

Copyright for this article is retained by the author(s), with first publication rights granted to the journal.

This is an open-access article distributed under the terms and conditions of the Creative Commons Attribution license (http://creativecommons.org/licenses/by/4.0/). 